\title{
PELATIHAN PERENCANAAN PARTISIPATIF DALAM PENATAAN KAWASAN KUMUH MERANTI KOTA PEKANBARU
}

\author{
Lusi Dwi Putri \\ Prodi Teknik Sipil, Fakultas Teknik, Universitas Lancang Kuning \\ e-mail: lusidwiputri@unilak.ac.id
}

\begin{abstract}
Event PKM aims to assist partners in developing participatory planning which is the document Plan Environmental Restructuring Settlement / RPLP containing information on land-use planning slum settlement of the rate base $(R T / R W)$ and collected in the village include a profile of settlements, mapping self, action plans base and indicative program. Formulation handling priority scale slum city in 2017 should refer to the documents this RPLP.Targets and outcomes to be achieved are the application of community learning services (improve understanding partners to map the potential and the problems in their own communities in a participatory), reports and scientific articles (journals / proceedings). The methods used are learning in the classroom and on the field/practice. The method used in the form of lectures, discussions and question and answer and On The Job Training / OJT. The results obtained are partners understand about the document RPLP, from 24 (twenty-four) participants with a value of 'Very Good' by $45.8 \%$, the value of 'Good' $37.5 \%$ value 'Medium' $16.7 \%$ and the value of 'No Show' at $0 \%$. Partners are also able to practice the selfmapping and action plans to formulate a basic level. Other results in the form of articles to be published. The conclusion is increasing the capacity of partners in planning participatory environmental management through a strategic role Participatory Planning Core Team
\end{abstract}

Keywords - participatory planning, slum, city dwellers

\begin{abstract}
ABSTRAK
Kegiatan PKM ini bertujuan membantu mitra dalam menyusun perencanaan secara partisipatif yaitu dokumen Rencana Penataan Lingkungan Permukiman/RPLP yang berisikan informasi perencanaan penataan kawasan kumuh permukiman dari tingkat basis ( $R T / R W)$ dan dihimpun di tingkat kelurahan mencakup profil permukiman, pemetaan swadaya, rencana aksi tingkat basis dan indikasi program. Rumusan penanganan kawasan kumuh prioritas skala kota tahun 2017 harus mengacu pada dokumen RPLP ini. Target dan luaran yang ingin dicapai adalah penerapan jasa pembelajaran masyarakat dengan cara meningkatkan pemahaman mitra dalam memetakan potensi dan permasalahan di lingkungan mereka sendiri secara partisipatif. Metode yang digunakan adalah pembelajaran di kelas dan di lapangan/praktik. Metode yang digunakan berupa ceramah, diskusi dan tanya jawab serta On The Job Training/OJT. Hasil yang diperoleh adalah mitra memahami tentang dokumen RPLP, dari 24 (dua puluh empat) orang peserta dengan nilai 'Sangat Baik' sebesar 45,8\%, nilai 'Baik' sebesar 37,8\% nilai 'Sedang' 16,8\% dan nilai 'Tidak Tampil' sebesar 0\%. Mitra juga mampu membuat rumusan rencana aksi tingkat basis. Kesimpulan yang diperoleh adalah meningkatnya kapasitas mitra dalam perencanaan penataan lingkungan secara partisipatif melalui peran strategis Tim Inti Perencanaan Partisipatif (TIPP).
\end{abstract}

Kata kunci : perencanaan partisipatif, kumuh, permukiman

\section{PENDAHULUAN}

Ditjen Cipta Karya menyiapkan Program Kota Tanpa Kumuh (KOTAKU) sebagai upaya strategis memberdayakan masyarakat dan memperkuat peran pemda. KOTAKU menggunakan sinergi platform kolaborasi antara Pemerintah Daerah dan pemangku kepentingan lainnya termasuk perguruan tinggi di Kabupaten/Kota serta Pembangunan Infrastruktur Berbasis Masyarakat untuk 
mempercepat penanganan kumuh perkotaan dan gerakan 100-0-100 dalam rangka mewujudkan permukiman yang layak huni, produktif dan berkelanjutan. Kelurahan Sri Meranti termasuk salah satu dari 19 (sembilan belas) kelurahan dari 58 (lima puluh delapan) kelurahan se-Kota Pekanbaru yang masuk dalam daftar SK Walikota No.151/tahun 2016 tentang Kawasan Kumuh di Kota Pekanbaru.

Rumusan penanganan kawasan kumuh prioritas skala kota tahun 2017 harus mengacu pada Dokumen Perencanaan Partisipatif di tingkat masyarakat/kelurahan (Rencana Penataan Lingkungan Permukiman/RPLP). Namun pada kenyataannya masyarakat/mitra kesulitan dalam menyusun dokumen ini. Mitra belum memahami bagaimana menyusun profil permukiman kelurahan, membangun visi, pelaksanaan pemetaan swadaya dan penyusunan RPLP. Ini perlu kedalaman analisa teknis, sehingga masyarakat atau mitra butuh sumbangan pemikiran dari kalangan akademisi.

Terkait permasalahan masyarakat di Kelurahan Sri Meranti solusi yang ditawarkan adalah memberikan pelatihan Perencanaan Partisipatif. Pelatihan perencanaan partisipatif adalah pelatihan/penguatan kapasitas masyarakat dalam membuat satu dokumen perencanaan dengan melibatkan semua unsur yang ada di masyarakat (aparat kelurahan, lembaga yang ada di masyarakat serta relawan) dengan mengedepankan pola partisipatif yaitu "dari, oleh dan untuk rakyat". Perencanaan partisipatif tersebut dimulai dengan membangun visi, refleksi perkara kritis, pemetaan swadaya dan penyusunan dokumen perencanaan partisipatif itu sendiri yang disebut dokumen RPLP. Perencanaan partisipatif ini dikawal oleh sebuah tim yang dibentuk dan di sahkan oleh Kepala Kelurahan yaitu Tim Inti Perencanaan Partisipatif (TIPP) bentukan Program KOTAKU. Mitra kegiatan pelatihan ini adalah TIPP Kelurahan Sri Meranti Kecamatan Rumbai Kota Pekanbaru.

\section{METODE}

Metode pelaksanaan yang digunakan dalam kegiatan pengabdian kepada masyarakat di Kelurahan Sri Meranti ini adalah sebagai berikut :

1. Diskusi dan Tanya Jawab

Substansi yang disampaikan adalah :

a. Pengertian Perencanaan Partisipatif :

- Proses perumusan dan penyepakatan produk perencanaan dengan melibatkan partisipasi aktif warga dan Pemda

- Proses penyelarasan perencanaan pembangunan Kota (top down) dan perencanaan pembangunan yang dirumuskan masyarakat secara partisipatif (bottom up)

- Dokumen Perencanaan Partisipatif (RPLP)

b. Manfaat :

- Menumbuhkan rasa memiliki dan tanggung jawab yang kuat terhadap hasil pembangunan.

- Meminimalkan konflik, sehingga mempercepat proses kegiatan secara keseluruhan.

- Efisiensi dan efektivitas, karena keputusan diambil sesuai dengan kondisi yang ada, baik kebutuhan, keinginan, maupun sumber daya di masyarakat.

- Memberdayakan masyarakat setempat, terutama membangun kepercayaan diri, kemampuan bermasyarakat dan bekerja sama.

2. On The Job Training (OJT)/Praktik

Metode praktik ini digunakan dengan tujuan akhir mitra mampu melaksanakan tahapan perencanaan partisipatif pada kondisi yang sesungguhnya.

3. Monev Pelaksanaan dan Keberlanjutan 
Monev pelaksanaan dan keberlanjutan merupakan suatu sistem yang digunakan setelah selesai pelaksanaan kegiatan pengabdian kepada masyarakat. Bentuk monev tersebut adalah sebagai berikut :

a. Evaluasi nilai pre-test dan post-test

Untuk mengetahui sejauh mana pelaksanaan kegiatan pelatihan, telah dilakukan evaluasi penilaian peserta. Nilai tersebut dihitung dari pelaksanaan Pre Test dan Post Test dengan rumus sebagai berikut :

$$
\text { Nilai }=\frac{\text { Jumlah soal bernilai benar }}{\text { Jumlah soal keseluruhan }} \times 100
$$

b. Evaluasi topik belajar

Untuk mengetahui seberapa jauh pemahaman mitra terhadap topik pembelajaran dapat dilihat pada evaluasi topik belajar yang diberikan berupa kuisioner kepada mitra.

c. Evaluasi pemandu

Untuk mengetahui seberapa jauh penguasaan materi oleh pemandu terhadap topik belajar yang disampaikan kepada mitra dapat dilihat pada Evaluasi Pemandu yang diberikan berupa kuisioner kepada mitra.

d. Evaluasi pelaksanaan OJT

Untuk mengetahui kemampuan mitra sebagai TIPP dalam memfasilitasi perencanaan partisipatif di lingkungan basis masing-masing mitra nantinya (di RT/RW), perlu dilakukan evaluasi pelaksanaan OJT yang dapat dilihat pada saat mitra melakukan simulasi/praktik kegiatan.

e. Pendampingan dokumen RPLP

\section{HASIL DAN PEMBAHASAN}

Hasil yang diperoleh dari kegiatan PKM ini diuraikan sebagai berikut :

a. Tempat Pelatihan

Kegiatan pelatihan dilaksanakan di Sekretariat Lembaga Keswadayaan Masyarakat (LKM) Meranti Jaya Kelurahan Sri Meranti Kecamatan Rumbai yang beralamat di Jalan Siak Kelurahan Sri Meranti Kecamatan Rumbai Kota Pekanbaru.

b. Peserta Pelatihan

Peserta pelatihan berjumlah 20 (dua puluh) orang yang diusulkan, namun pada pelaksanaan ada penambahan peserta dari unsur relawan sehingga total peserta berjumlah 24 (dua puluh empat) orang.

c. Pengamatan Peserta

Dari proses pelatihan dinamika peserta berjalan dengan baik, terjadi komunikasi 2 (dua) arah yang bersifat dialogis dan kritis.

d. Topik dan Pemandu

Secara umum topik yang disampaikan pemandu sudah memenuhi kebutuhan pelatihan, namun untuk mengetahui seberapa jauh melihat topik dan pemandu dapat dilihat pada Evaluasi Topik dan Pemandu melalui beberapa aspek penilaian sebagai berikut : 
Tabel 1 Evaluasi Topik Belajar-1

Topik 1 : Penyusunan Profil Permukiman

\begin{tabular}{|c|c|c|c|c|c|}
\hline \multirow{2}{*}{ ASPEK } & \multicolumn{5}{|c|}{ TOTAL KRITERIA } \\
\cline { 2 - 6 } & $\begin{array}{c}\text { SANGAT } \\
\text { KURANG }\end{array}$ & KURANG & SEDANG & BAIK & $\begin{array}{c}\text { SANGAT } \\
\text { BAIK }\end{array}$ \\
\hline \hline 1 & 0 & 0 & 5 & 14 & 5 \\
2 & 0 & 0 & 5 & 14 & 5 \\
3 & 0 & 0 & 2 & 14 & 8 \\
4 & 0 & 0 & 4 & 15 & 5 \\
5 & 0 & 0 & 2 & 16 & 6 \\
6 & 0 & 0 & 3 & 15 & 6 \\
7 & 0 & 0 & 1 & 10 & 13 \\
\hline
\end{tabular}

Berikut grafik hasil evaluasi topik belajar-1 :

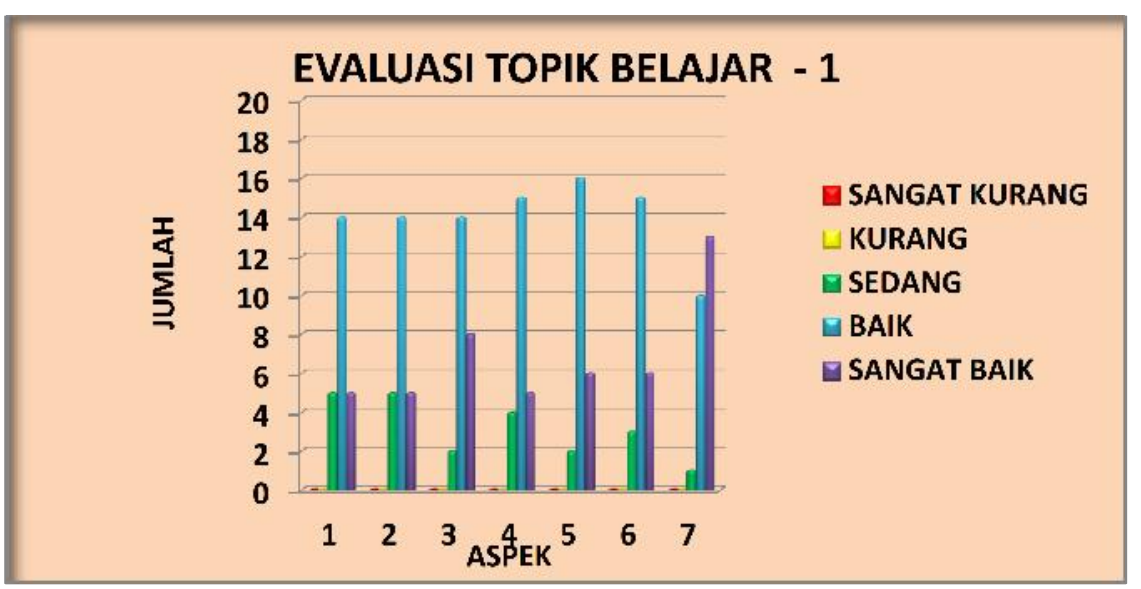

Gambar 1. Evaluasi Topik Belajar-1

Tabel 2 Evaluasi Topik Belajar-2

Topik 2: Membangun Visi

\begin{tabular}{|c|c|c|c|c|c|}
\hline \multirow{3}{*}{ ASPEK } & \multicolumn{5}{|c|}{ TOTAL KRITERIA } \\
\cline { 2 - 6 } & $\begin{array}{c}\text { SANGAT } \\
\text { KURANG }\end{array}$ & KURANG & SEDANG & BAIK & $\begin{array}{c}\text { SANGAT } \\
\text { BAIK }\end{array}$ \\
\hline \hline 1 & 0 & 0 & 3 & 17 & 4 \\
2 & 0 & 0 & 5 & 17 & 2 \\
3 & 0 & 0 & 2 & 15 & 7 \\
4 & 0 & 0 & 6 & 16 & 2 \\
5 & 0 & 0 & 3 & 17 & 4 \\
6 & 0 & 0 & 3 & 16 & 5 \\
7 & 0 & 0 & 1 & 13 & 10 \\
\hline
\end{tabular}

Berikut grafik hasil evaluasi topik belajar-2 : 




Gambar 2. Evaluasi Topik Belajar-2

Tabel 3 Evaluasi Topik Belajar-3

Topik 3 : Pemetaan Swadaya

\begin{tabular}{|c|c|c|c|c|c|}
\hline \multirow{3}{*}{ ASPEK } & \multicolumn{5}{|c|}{ TOTAL KRITERIA } \\
\cline { 2 - 6 } & $\begin{array}{c}\text { SANGAT } \\
\text { KURANG }\end{array}$ & KURANG & SEDANG & BAIK & $\begin{array}{c}\text { SANGAT } \\
\text { BAIK }\end{array}$ \\
\hline \hline 1 & 0 & 0 & 5 & 12 & 7 \\
2 & 0 & 0 & 6 & 15 & 3 \\
3 & 0 & 0 & 0 & 18 & 6 \\
4 & 0 & 0 & 4 & 16 & 4 \\
5 & 0 & 0 & 4 & 15 & 5 \\
6 & 0 & 0 & 3 & 16 & 5 \\
7 & 0 & 0 & 0 & 13 & 11 \\
\hline
\end{tabular}

Berikut grafik hasil evaluasi topik belajar-3 :



Gambar 3. Evaluasi Topik Belajar-3

Tabel 4 Evaluasi Topik Belajar-4

Topik 4 : Penyusunan RPLP 
DINAMISIA - Jurnal Pengabdian Kepada Masyarakat $\quad$ Vol. 1, No. 1 Desember 2017, hal. 129-137

\begin{tabular}{|c|c|c|c|c|c|}
\hline \multirow{2}{*}{ ASPEK } & \multicolumn{5}{|c|}{ TOTAL KRITERIA } \\
\cline { 2 - 6 } & $\begin{array}{c}\text { SANGAT } \\
\text { KURANG }\end{array}$ & KURANG & SEDANG & BAIK & $\begin{array}{c}\text { SANGAT } \\
\text { BAIK }\end{array}$ \\
\hline \hline 1 & 0 & 0 & 4 & 15 & 5 \\
2 & 0 & 0 & 4 & 16 & 4 \\
3 & 0 & 0 & 3 & 15 & 6 \\
4 & 0 & 0 & 3 & 17 & 4 \\
5 & 0 & 0 & 3 & 14 & 7 \\
6 & 0 & 0 & 2 & 18 & 4 \\
7 & 0 & 0 & 2 & 10 & 12 \\
\hline
\end{tabular}

Berikut grafik hasil evaluasi topik belajar-4 :

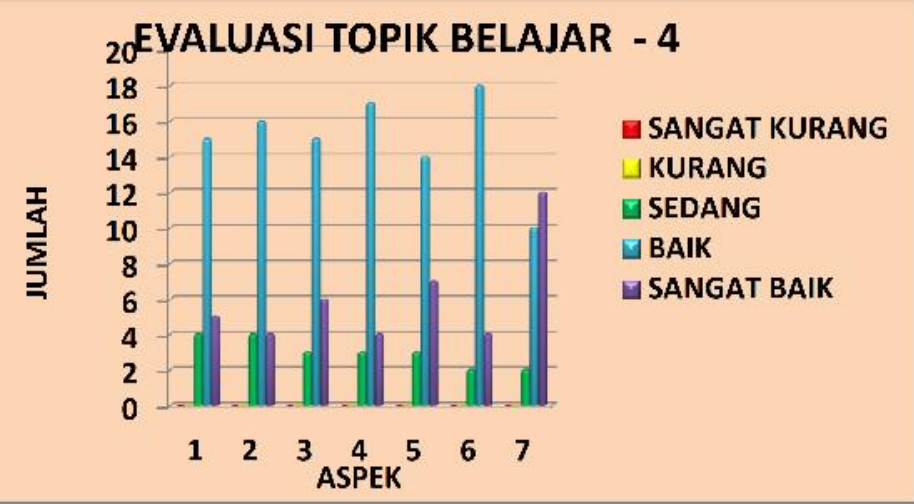

Gambar 4. Evaluasi Topik Belajar-4

\section{Penilaian Peserta Pelatihan}

Untuk mengetahui sejauh mana pelaksanaan kegiatan pelatihan, telah dilakukan evaluasi penilaian peserta. Nilai tersebut dihitung dari pelaksanaan Pre Test dan Post Test dengan rumus sebagai berikut :

$$
\text { Nilai }=\frac{\text { Jumlah soal bernilai benar }}{\text { Jumlah soal keseluruhan }} \times 100
$$

Contoh perhitungan, sebelum dilaksanakan kegiatan pengabdian kepada masyarakat kegiatan Pre Test, dari 11 soal yang diberikan ternyata ada 3 (tiga) soal yang dijawab benar dengan perhitungan sebagai berikut :

$$
\text { Nilai }=\frac{3}{11} \times 100=27
$$

Setelah mengikuti kegiatan pengabdian kepada masyarakat sampai selesai pada sesi terakhir pada kegiatan Post Test, dari 11 soal yang diberikan ternyata 11 (sebelas) soal dijawab benar dengan perhitungan sebagai berikut :

$$
\text { Nilai }=\frac{11}{11} \times 100=100
$$

Dari hasil rekapitulasi diatas, peningkatan pemahaman subtansi sebelum dan sesudah dilaksanakan sangat signifikan kenaikannya. 


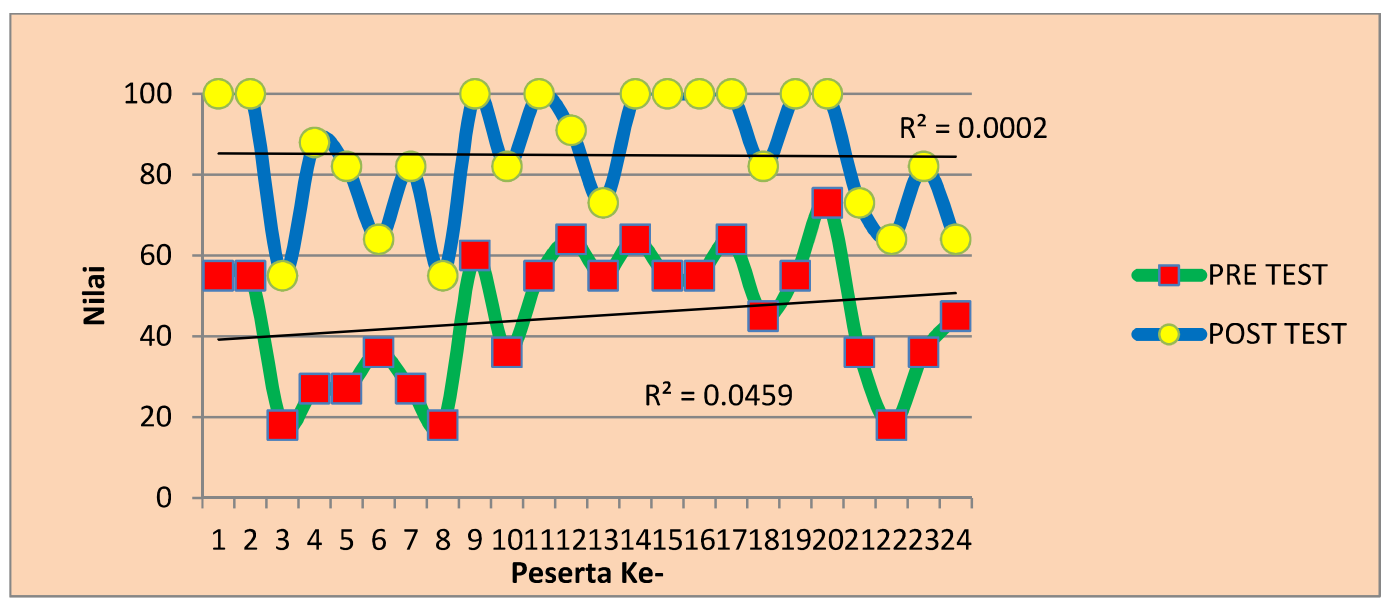

Gambar 5. Nilai Pre Test dan Post Test Peserta

Dari grafik nilai Pre Test dan Post Test peserta pada gambar 5 diperoleh bahwa nilai yang diperoleh peserta ada yang lebih tinggi dari peserta lainnya begitu juga sebaliknya ada peserta yang lebih rendah dari peserta lainnya. Selama kegiatan berlangsung kami mengamati bahwa peserta yang memiliki nilai yang lebih tinggi dari peserta lainnya dkarenakan peserta tersebut terlihat aktif selama kegiatan berlangsung seperti bertanya setiap tidak memahami substansi yang disampaikan oleh tim pemandu serta memiliki wawasan yang luas terkait kegiatan infrastruktur. Peserta yang memiliki nilai lebih rendah dari peserta lainnya, berdasarkan hasil pengamatan tim pemandu mereka kurang aktif untuk bertanya, bahkan umpan balik yang diberikan oleh tim pemandu pun tidak direspon hal ini dikarenakan kemampuan masing-masing individu berbeda dalam memahami substansi yang diberikan melalui pelatihan yang hanya diberikan pada jangka waktu yang belum maksimal.

\section{Hasil Akhir Pelatihan} 6 berikut.

Rekapitulasi hasil akhir pelatihan dari semua peserta dapat dilihat pada grafik dalam gambar

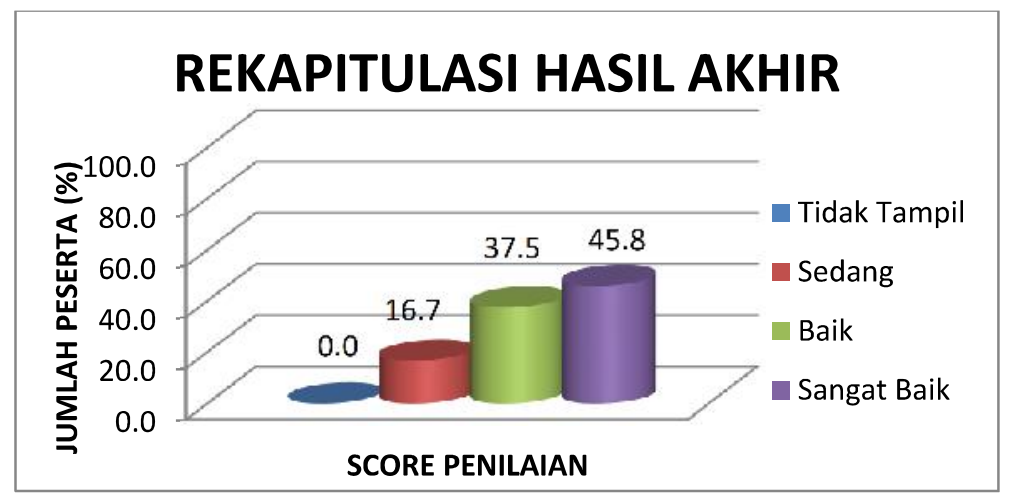

Gambar 6. Rekapitulasi Hasil Akhir

Peningkatan kemampuan peserta terhadap subtansi mengalami peningkatan, banyak peserta yang awalnya masih bingung dengan konsep dan fasilitasi perencanaan teknis infrastruktur namun pada akhirnya mulai terbuka wawasan dan dukungan peserta untuk melaksanakan kegiatan . Terbukti pada grafik dalam gambar 6 dapat dilihat bahwa dari seluruh peserta terdapat 83,3\% memperoleh nilai akhir Sangat Baik dan Baik. Nilai Baik sebesar 37,5 \% dan nilai Sangat Baik sebesar 45,8\%. Hanya $16,7 \%$ peserta yang memperoleh nilai Sedang. 




Gambar 7. Foto bersama dengan peserta yang tergabung dalam TIPP

\section{Pembahasan}

Kelurahan Sri Meranti termasuk salah satu permukiman yang masih perlu dilakukan perbaikan infrastruktur dasar. Masih banyak usulan prioritas kegiatan dari level RT/RW yang belum bisa direalisasikan padahal sudah masuk dalam Musrenbang. Masyarakat di level RT/RW juga memiliki pengetahuan yang terbatas terhadap berbagai program perbaikan infrastruktur dasar baik bersumber dari pemerintah maupun swasta .

Dari hasil pelatihan yang diberikan melalui kegiatan ini diperoleh tingkat pemahaman masyarakat sebelumnya terkait perencanaan partisipatif masih sangat rendah yaitu rata-rata $45 \%$. Peserta kurang memahami bahkan cendrung baru mengetahui tentang materi yang diberikan. Namun dengan adanya proses sharing antara peserta memudahkan pemahaman substansi yang diberikan. Peran pelaku utama yaitu TIPP maupun tokoh kunci di masyarakat sangat diharapkan seperti peran Ketua RT dan Ketua RW yang berada di tingkat basis. Kemampuan Ketua RT/RW dalam menggerakkan dan memotivasi masyarakatnya untuk perencanaan lingkungan berperan besar demi tujuan substansi yang diberikan.

Setelah melalui kegiatan ini kemampuan peserta menyerap substansi yang diberikan ratarata $85 \%$ memperoleh nilai akhir minimal Baik. Konsep pelatihan yang mengembangkan konsep komunikasi terbuka, peserta pelatihan bisa mempererat silaturahmi dalam rangka membuka jaringan informasi dan tukar pendapat terkait dengan masalah dan kendala serta upaya teknis atas keberhasilan perencanaan di kelurahan umumnya dan di tingkat basis khususnya. Setelah terbangunnya jaringan komunikasi yang terbuka antara basis (RT/RW).

\section{Keberlanjutan}

Rencana investasi kegiatan pencegahan dan peningkatan kualitas kawasan kumuh kelurahan Sri Meranti ini dikawal hingga menjadi bahan diskusi maupun desk evaluasi di tingkat kota maupun provinsi pada program Kota Tanpa Kumuh (KOTAKU). Beberapa kegiatan yang telah diikuti untuk tujuan ini seperti :

1. Lokakarya Tingkat Kota Pekanbaru

Pemaparan kegiatan penangan kumuh, FGD dan diskusi tingkat Kota dihadiri oleh Satker PKP, DPRD Kota, Bappeda Kota, Perguruan Tinggi, SKPD, Camat, Konsultan dan Forum LKM Kota Pekanbaru

2. Konsultasi Publik Tahap 1

Pemaparan hasil perencanaan di tingkat kelurahan prioritas SK Kumuh, FGD dan diskusi dihadiri oleh Satker PKP, DPRD Kota, Bappeda Kota, Perguruan Tinggi, SKPD, Camat, Konsultan dan Forum LKM Kota Pekanbaru.

3. Konsultasi Publik Tahap 2

Desk evaluasi perencanaan di tingkat kelurahan prioritas SK Kumuh dengan dihadiri oleh Satker PKP, Bappeda Kota, Pokja PKP, Perguruan Tinggi, SKPD dan Lurah.

4. Konsultasi Publik Tahap 3 dan finalisasi dokumen perencanaan partisipatif/RPLP menjadi dokumen skala kota yang di sahkan oleh walikota Pekanbaru 


\section{KESIMPULAN}

Dari semua tahapan kegiatan pengabdian yang dilakukan maka dapat diambil kesimpulan sebagai berikut :

1. Meningkatnya kapasitas mitra dalam perencanaan teknis infrastruktur permukiman, dimana tingkat pemahaman masyarakat terkait infrastruktur permukiman sebelum adanya kegiatan IbM masih sangat rendah yaitu sebesar $44 \%$ dan setelah mengikuti kegiatan naik menjadi $85 \%$ (tujuh puluh lima persen).

2. Hasil akhir pelatihan untuk peserta dengan nilai 'Sangat Baik' sebesar $45,8 \%$, nilai 'Baik' sebesar $37,5 \%$ nilai 'Sedang' $16,7 \%$ dan nilai 'Tidak Tampil' sebesar $0 \%$.

3. Meningkatnya peran serta mitra dalam membangun kultur pembelajaran yang terorganisasi melalui komunitas belajar secara berkelanjutan

\section{SARAN}

Dari semua data yang ada disarankan :

1. Diharapkan ada kegatan lanjutan dari pengabdian masyarakat ini agar target utama yang diharapkan dapat terlaksana yaitu terpenuhi semua kebutuhan masyarakat untuk infrastruktur permukiman yang layak.

2. Ada sinergi dari semua pihak (pemerintah, swasta dan masyarakat) untuk mewujudkan infrastruktur permukiman yang layak secara berkelanjutan.

\section{DAFTAR PUSTAKA}

[1] Departemen Pekerjaan Umum Dirjen Cipta Karya, 2008, Persiapan dan Perencanaan Teknis Infrastruktur, PNPM Mandiri Perkotaan

[2] Departemen Pekerjaan Umum Dirjen Cipta Karya, 2011, Strategi Pengembangan Kapasitas, PNPM Mandiri Perkotaan

[3] Republik Indonesia, 2011, Undang-Undang No. 1/2011tentang Perumahan dan Kawasan Permukiman, Lembaran Negara RI Tahun 2011, No 7, Sekretariat Negara RI

[4] Satuan Kerja Pengembangan Kawasan Permukiman dan Penataan Bangunan (PKP2B) Provinsi Riau, 2015, Kebijakan NasionalProgram Peningkatan Kualitas Permukiman Direktorat Cipta Karya, Satker PKP2B Riau

[5] Sistem Informasi Manajemen Program Peningkatan Kualitas Kawasan Permukiman, 2016, Kelengkapan Data Lokasi Kumuh Baseline 100-0-100. Aviable from: http://sim.p2kp.org/p2kp/report/kelengkapan_data_kumuh.php?kode=14, Accesed : 2016, February 7

[6] Tim Nasional Percepatan Penanggulangan Kemiskinan (TNP2K), 2012, Agenda Pembangunan Global Pasca 2015, Sekretariat Wakil Presiden RI 